Jahrbuch Schweiz - Dritte Welt 1991

\title{
Schweiz vor einem möglichen Beitritt zum IWF und der Weltbank
}

La Suisse face à une éventuelle entrée au FMI et à la Banque Mondiale (BM)

\section{Mario Carera}

\section{(2) OpenEdition}

12 Journals

Édition électronique

URL : http://journals.openedition.org/sjep/1228

DOI : $10.4000 /$ sjep. 1228

ISSN : 1663-9677

Éditeur

Institut de hautes études internationales et du développement

\section{Édition imprimée}

Date de publication : 1 janvier 1991

Pagination : 215-218

ISSN : 1660-5926

\section{Référence électronique}

Mario Carera, "Schweiz vor einem möglichen Beitritt zum IWF und der Weltbank », Schweizerisches Jahrbuch für Entwicklungspolitik [En ligne], 10 | 1991, mis en ligne le 14 avril 2013, consulté le 08 septembre 2020. URL : http://journals.openedition.org/sjep/1228 ; DOI : https://doi.org/10.4000/sjep. 1228

Ce document a été généré automatiquement le 8 septembre 2020

(c) The Graduate Institute 


\section{Schweiz vor einem möglichen Beitritt zum IWF und der Weltbank}

La Suisse face à une éventuelle entrée au FMI et à la Banque Mondiale (BM)

Mario Carera

\section{NOTE DE L'ÉDITEUR}

Volltext auf Französisch in Annuaire suisse de politique de développement: „La Suisse face à une éventuelle entrée au FMI et à la Banque Mondiale (BM)", http://aspd.revues.org/ 1380. 